\title{
THE NAMIBIAN LABOUR DISPUTE RESOLUTION SYSTEM: SOME LESSONS FROM SOUTH AFRICA*
}

"The use of the comparative method requires knowledge not only of the foreign law, but also of its social, and above all, its political context. The use of comparative law for practical purposes becomes an abuse only if it is informed by a legalistic spirit, which ignores this context of the law" (Blanpain and Millard Comparative Labour Law and Industrial Relations (1992) 17).

\section{Introduction}

In Namibia and South Africa respectively, there are social partners (social partners are the workers' and employers' organisations in terms of the ILO classification) with common and divergent short- and long-term interests. These divergent interests must be accommodated and reconciled and this process is the subject of labour law and industrial relations. However, the processes employed in Namibia and South Africa vary (Blanpain and Millard Comparative Labour Law and Industrial Relations 17).

The purpose of this comparative article is to highlight and explain the differences between and similarities of the two respective countries' labour dispute-resolution systems (Schregle "Comparative Industrial Relations: Pitfalls and Potential" 1981 International Labour Review 27). This comparative approach brings to bear two schools of thought, the first being the convergence school, and the second is the divergence school (Finnemore and Van Rensburg Contemporary Labour Relations (2002) 5). The convergence school holds that the influence of industrialisation gradually brings the labour-relations systems of various countries closer to one another. The divergence school, on the other hand, maintains that labour relations are sub-systems of political systems and manifestations of prevailing social and economic conditions.

Despite these perspectives above, it should not be taken for granted that systems and institutions are transplantable (Blanpain and Millard Comparative Labour Law and Industrial Relations 29) as it is argued that any attempt to do so may entail a wish of rejection. The reason for this view is premised on the basis that Namibia and South Africa are not identical; there are distinct differences in certain areas, such as economic development. However, the differences between the systems do not mean that Namibia cannot adopt solutions that have proved successful in South Africa or vice versa, and therefore a degree of transferability may be accepted.

This note is based on the doctoral degree of Felix Musukubili at the Nelson Mandela Metropolitan University, Port Elizabeth. This LLD was supervised by Prof JA van der Walt. 


\section{$2 \quad$ Historical analysis}

The South African post-apartheid labour regime has had a profound impact on labour law within the Southern African region. It has been the catalyst for a great number of reforms in Southern African Development Community (hereinafter "SADC") countries, particularly in the area of labour-dispute resolution (Benjamin in Bronstein International and Comparative Labour Law - The Challenges of Labour Law Reform in South Africa (2009) 255). This holds true for Namibia's Labour Act, 2007, which has established specialised institutions, such as the Labour Commissioner, to promote the use of conciliation and arbitration as the primary mechanisms for the prevention and resolution of labour disputes (see Chapter 8 Part E of the Labour Act 11 of 2007). In the same vein, the Labour Court system was established for adjudication as a last resort (see Chapter 8 Part D of the Labour Act 11 of 2007).

Prior to Namibian independence in 1990, the country was administered by South Africa as a C mandate in terms of the Peace Treaty of Versailles and article 22 of the Covenant of the League of Nations (Bauer Labour and Democracy in Namibia (1996) 19). At that time, the mandate empowered the South African Government to exercise full administrative and legislative power over South West Africa, now Namibia. The article submits that the SWAPO-led Government brought about the demise of South Africa's colonial occupation of Namibia, led by Sam Shafishuna Nujoma, who later became the first President of the Republic of Namibia.

During South Africa's occupation of Namibia the country had no comprehensive labour legislation in place. However, as South West Africa was seen as South Africa's fifth province, it is submitted that most laws that were passed in South Africa were immediately duplicated in Namibia, or closely resembled those of South Africa (Van Rooyen Portfolio of Partnership - An Analysis of Labour Relations in a Transistional Society Namibia (1996)). In this respect, the Namibian Master and Servants Proclamation Act (24 of 1920), is identified as having had similar provisions to the Industrial Conciliation Act (11 of 1924) in South Africa, and the Wages and Industrial Conciliation Ordinance (35 of 1952), comparative to the South African Industrial Conciliation Act (28 of 1956), which were both discriminatory to African workers.

The Wiehahn Commission brought about significant changes to the labour-relations system in South Africa, prior to the country's first democratic elections in 1994 (Godfrey, Maree, Du Toit and Theron Collective Bargaining in South Africa (2010) 57). A similar commission, led by Professor Wiehahn, was constituted shortly before Namibia's independence and was tasked with investigating labour matters in the country (Van Rooyen Portfolio of Partnership 217). This article asserts that the Wiehahn Commission's recommendations had been gradually implemented, with the first changes brought about by the enactment of the post-independence Labour Act of 1992 and later changes implemented through the current Labour Act of 2007.

Namibia and South Africa are commended for adopting constitutions that guarantee the protection of basic labour rights and for undertaking labour 
reforms to give effect to constitutionally entrenched labour rights, with the aim of regulating all facets of labour relationships. To this end, Namibia enacted the Labour Act of 1992, which later become inadequate in resolving labour disputes, leading to the passing of the current Labour Act of 2007. It is suggested that this Act substantially altered labour law in Namibia and created a new framework for the resolution of labour disputes.

Evidence suggests that the changes made to the machinery for the resolution of labour disputes reflect a consensus that its predecessors, as set out in the 1992 Act, were not functioning effectively (Fenwick Labour Law Namibia (2007) 39). The Labour Act of 2007 shifted the emphasis to conciliation and arbitration by the Labour Commissioner. Given the backdrop of the repealed 1992 Act, it is submitted herein that the new approach of non-confrontation and based on user-friendly procedures that suit the parties to labour disputes, instead of adversarial, court-based methods are preferred (Fenwick Labour Law Namibia 40).

Without any doubt, the changes in the Namibian labour-dispute resolution system resemble that of South Africa, where the negotiated LRA of 1995 was enacted to replace the 1956 LRA. From this premise, the LRA was enacted to promote, among other things, an effective and efficient labourdispute resolution system (s (1)(d)(iv) of the LRA 66 of 1995). It was expected to overcome the problems faced by its predecessor.

\section{$3 \quad$ Prevailing practices}

The South African LRA has decriminalized labour law by removing the use of criminal law to enforce labour law and collective agreements. It is submitted that the inclusion of criminal provisions in labour legislation violates international labour standards. Having moved away from criminal sanctions to enforce labour laws, South Africa adopted an approach of selfregulation and enforcement through private-law interventions, such as statutory arbitration, private arbitration and adjudication by the Labour Court (Brassey Commentary on the Labour Relations Act A1-4). In Namibia, despite the Wiehahn Commission's recommendations to decriminalize labour-law contraventions, the drafters of both the 1992 Act and the Labour Act of 2007 ignored these recommendations and permitted the inclusion of criminal sanctions in labour legislation. The Namibian police and prosecutors experience serious difficulties in ensuring the successful prosecution and conviction of offenders due to the complexity of related charges. Consequently, this article contends that there is no purpose in the inclusion of such criminal provisions, given the very low rate of success (if any) in bringing offenders before criminal courts.

The Labour Commissioner's office and the Commission for Conciliation Mediation and Arbitration (hereinafter the "CCMA") are comparable institutions created by the respective countries' labour legislations to promote and provide the framework for the effective and efficient resolution of labour disputes. In Namibia, the Labour Commissioner is an individual civil servant, appointed by the Minister of Labour (s 120 of the Labour Act 11 of 2007), and includes conciliators and arbitrators in his office (see ss 82(2) and $85(4)$ of the Labour Act 11 of 2007). As a result, social partners have 
very little input with regard to decisions made in the appointment of the Labour Commissioner, conciliators and arbitrators, save for playing an advisory role in establishing the terms of conciliators' and arbitrators' qualifications (s 100(iv) of the Labour Act 11 of 2007). In South Africa, it is different though, in that the CCMA is established as an autonomous statutory body with legal personality (s 112 of the LRA 66 of 1995). The director and commissioners are appointed by the governing council of the CCMA. The CCMA is, without a doubt, independent of the state, political parties, trade unions and employers' organizations (s 113 of the LRA 66 of 1995). This is not the case in Namibia, despite recommendations by the Taskforce responsible for drafting the Labour Act that the Labour Commissioner be independent of the state. Nevertheless, it should be noted that the Namibian Labour Act places a great deal of emphasis on the independence and impartiality of the Labour Commissioner and all arbitrators in the performance of their statutory functions, despite their appointment as civil servants (s 85 of the Labour Act 11 of 2007).

As it was stated earlier, the LRA adopted the ADR systems of conciliation and arbitration and created the Labour Court as last resort in dispute resolution. It is clear that Namibia followed South Africa's example with the enactment of the Labour Act, 2007, therefore confirming that the current Namibian labour-dispute resolution system has been "borrowed or transplanted" from South Africa (Fenwick Labour Law in Namibia 45). However, minor differences do exist.

Although the principles of conciliation are similar in both countries, the original Labour Act of 2007 empowered conciliators to determine labour disputes at conciliation level (s 83 of the Labour Act 11 of 2007). This created the perception that conciliation meetings had similar trappings to a court or tribunal, which produced binding awards. The Namibian Labour Court has since condemned this provision and practice by pointing out that conciliation is simply an avenue to resolve labour disputes without necessarily having to make legally binding awards against any party to a dispute (Purity Manganese (Pty) Ltd v Tjeripo Katzao case no LC 80/2010 par 29). This provision has since been altered by the Labour Amendment Act (2 of 2012). In South Africa, since the inception of conciliation, commissioners had no binding determination powers at conciliation level.

There are practical differences between the Namibian and South African ADR systems in terms of referral timelines for interest and rights disputes. In Namibia, interest disputes are referred to the Labour Commissioner within one year, while rights disputes, such as dismissals, are referred within six months from the date the cause of action arose (s 86 of the Labour Act 11 of 2007). In South Africa, dismissal disputes must be referred within 30 days, while unfair labour-practice and discrimination disputes must be referred to the CCMA within six months of the dispute arising (s 191 of the LRA 66 of 1995). Interestingly, there is a statutory provision for condonation for late referral on good cause shown in South Africa (s 191(2) of the LRA 66 of 1995), while there is no such provision in the Labour Act in Namibia, save for the provision in the Rules of the Labour Commissioner. The Labour Court in Namibia has stressed that a dispute referred after the expiry of the six-month period is out of time and, consequently, prescribed in terms of section 82 of 
the Labour Act (Standard Bank Namibia v Romeo Mouton case no 04/2011 delivered on 29 July 2011 par 9). For this reason, it is submitted that the absence of condonation provisions in the enabling statute, if challenged in the Labour Court, could render condonation provisions in the Rules of the Labour Commissioner null and void.

In respect to representation, such representation is limited to the parties at conciliation meetings, as stated in the LRA and the Labour Act, 2007. In South Africa, legal representatives, including consultants, are not permitted at conciliation level. In Namibia, legal representation and consultants are permitted on the agreement of the parties to the dispute and at the discretion of the conciliator (s 82(12), (13) and (14) of the Labour Act 11 of 2007). Accordingly, this article contends that that legal representation at conciliation turns the proceedings legalistic and expensive for ordinary parties to the dispute and, therefore, has the effect of negating a speedy and simplified labour-dispute resolution system.

In Namibia, despite the provision on settlement agreement, the Labour Act, 2007 has not created any mechanism for enforcing these agreements resulting from conciliation. The only remedy is to approach the Labour Court to make the settlement an order of court (see s 117 of the Labour Act 11 of 2007 providing for wider powers of the Labour Court). This lacuna allows parties to the dispute to enter into settlement agreements without the bona fide intention of resolving the dispute, knowing full well that there is no provision in the Labour Act compelling them to do so. Consequently, many settlement agreements remain in abeyance in Namibia. Namibia can learn from South Africa, which has a provision permitting the parties to approach the CCMA in order to convert a settlement agreement to an arbitration award, thereby acquiring the enforcement status of a usual arbitration award (s 142A of the LRA 66 of 1995).

The differences between the Namibian conciliation-arbitration (con-arb) process and that of South Africa are noted. In Namibia, con-arb was implemented with the enactment of the Labour Act, 2007 and currently directs that all disputes must go through a conciliation process before arbitration is sought (s 86(5) of the Labour Act 11 of 2007). There are only two exceptions to this provision: disputes of fundamental rights in terms of section 7 of the Labour Act, 2007, which may be taken directly to the Labour Court, and cases where the dispute has already been conciliated, for instance in collective bargaining disputes where the parties have agreed to refer the matter to arbitration (s 86(5) of the Labour Act 11 of 2007). In South Africa, con-arb is a relatively new intervention applicable to a limited range of disputes. Only specific disputes are permitted to make use of the con-arb process.

In a similar vein, parties to the con-arb process have the statutory privilege of objecting to the process; the same does not apply under Namibian labour law. These statutory privileges have resulted in a number of objections being raised about the con-arb process, creating a major challenge for the CCMA as parties seem to object to the process for no apparent reasons, possibly only to frustrate the other party's attempt to a speedy resolution of the dispute. Similarly, while the effectiveness of a dispute-resolution system depends substantially on its legitimacy, this 
attribute should not be compromised for efficiency. Focusing on the speed of con-arb proceedings could in some cases lead to the rapid settling of disputes and possible superficial settlements that fail to address the underlying causes of conflict or the real needs of the parties (Bhorat, Pauw and Mncube "Understanding the Efficiency and Effectiveness of the Dispute Resolution System - An Analysis of the CCMA" Development Policy Research Unit (UCT) 33).

On the other hand, an arbitration award must be issued within 30 days of the conclusion of an arbitration hearing by arbitrators in Namibia (s 86(18) of the Labour Act 11 of 2007) and within 14 days by CCMA commissioners in South Africa. In both cases the award is final and binding and automatically earns interest. However, in South Africa, the liability for interest ends when the debtor makes an unconditional offer to pay (see Top $v$ Top Reisen CC (2006) 27 ILJ 1948 LC). This is a result of the Labour Court's (see Mpanzama v Fidelity Guards Holdings (Pty) Ltd [2000] 12 BLLR 1459 (LC)) finding that an award is a debt and, as such, is subject to the Prescription Act (68 of 1969). In contrast, in Namibia the interest accumulates from the date of judgment or award to the date of payment and does not prescribe (JB Cooling and Refrigeration CC v Kasho Kavendjua case no LCA 15/2010 par 32).

The Director of the CCMA has the statutory power to certify the award, thereby making it enforceable immediately (s 143(1) and (3) of the LRA 66 of 1995). In Namibia, the Labour Commissioner has no such powers. It is for the parties or the Labour Commissioner at his/ her own instance to approach the Labour Court to make the award an order of court, consequently becoming enforceable (s 87(1)(a) and (b) of the Labour Act 11 of 2007). It is submitted that this creates further delays in Namibia when compared to the immediate enforcement of awards in South Africa, where approaching the court is an alternative rather than the first recourse.

In Namibia, despite the prescriptive instruction by the Labour Act, 2007 for statutory arbitration and the Labour Courts to take into account the code of good practice when deciding cases that come before them (s 86(17) of the Labour Act 11 of 2007), at the time of writing, Namibia had not developed and made available codes of good practice on a range of issues, including dispute resolution. Without any doubt, the codes of good practice, if promulgated, will facilitate proper implementation of the legislative framework and give users guidance on labour law and dispute resolution. Codes of good practice play a significant educational function and serve as an important dispute-prevention aid (Thompson Dispute Prevention and Resolution (2010) 33).

It has also been shown that in South Africa, the LRA provides clear guidelines for awarding compensation where, for instance, reinstatement is not a feasible option. For this reason the LRA places limitations on the awarding of compensation by commissioners and the Labour Court (s 194 of the LRA 66 of 1995). In Namibia, the Labour Act fails to provide similar guidelines on awarding compensation and, as such, unjustified compensation awards have been made by arbitrators in the Labour Commissioner's office. This has created varying opinions as to the permissible limit of compensatory awards. The Namibian Labour Court has 
also not been very helpful in this respect. All the Court was prepared to say is that compensation should be equal to the amount of loss suffered or the amount of remuneration the employee would have been paid had he not been dismissed (Pupkewitz Holdings (Pty) Ltd $v$ Petrus Mutamuka case no LCA47/2007 reportable). Clearly, this leaves it up to the arbitrator to award compensation from the date of dismissal to the date of the award, irrespective of the time that has elapsed. This equally applies to the Labour Court itself, where the amount of time it takes to finalize the matter is not taken into account. In most cases, this has led to arbitrators issuing vague arbitration awards that fail to specify the amount of and the time frame for compensation, making it effectively impossible to enforce by labour inspectors and to obtain writs of execution (s 90 of the Labour Act 11 of 2007).

There are two methods of enforcing arbitration awards in Namibia. Compensation awards are enforced by a writ of execution, while reinstatement is enforced by filing for contempt-of-court proceedings. In Namibia, the duty to enforce arbitration awards lies with labour inspectors who instruct the Deputy Sheriff to obtain a writ of execution. Contempt of court, on the other hand, is instituted by the Government Attorney on behalf of the labour inspector. In South Africa, labour inspectors play no role in the enforcement of arbitration awards. It is left to the parties themselves to pursue the enforcement at their own cost. This, for obvious reasons, may be unattainable for the ordinary party who may not be able to meet the costs involved. However, despite the involvement of the Government Attorney in the enforcement of reinstatement awards in Namibia, very little, if anything, has been achieved. At the time of writing, no contempt-of-court case had ever been brought before the court. This has led to a loss of confidence in the system by persons with unenforced reinstatement awards.

It has been found that the bargaining-council system in South Africa complements the work of the CCMA, thereby reducing the organization's case load and backlog (s 29 of the LRA 66 of 1995). In Namibia, there are no statutorily recognized bargaining-council systems, but industry-bargaining forums are prevalent. This is a progressive innovation initiated by the parties themselves, which operate on a purely voluntary basis. In the industries where bargaining forums exist, such as security, construction and farming, they have proved to be useful in terms of determining collective conditions of employment and setting of minimum standards of employment, such as minimum wages. However, they have no statutory power to resolve labour disputes, except referring such disputes to the Labour Commissioner's office.

Private arbitration is another alternative method of voluntary dispute resolution available to disputants in terms of the Arbitration Act (42 of 1965). Private arbitration in Namibia and South Africa is done in the same manner and premised on the same Arbitration Act. There are, however, no properly established and recognized private arbitration institutions in Namibia, such as Tokiso Dispute Resolution in South Africa. Therefore, parties have a limited choice in Namibia, except for agreeing on using the services of individuals practising as labour consultants. 
The private arbitration system plays a valuable complementary role in labour-dispute resolution as it has the potential to offer parties alternative adaptive and attuned formulas. It contributes benefits such as privacy, informality, speed, and focus on substance rather than form. This makes private arbitration cost-effective even where it is not publicly subsidized (Thompson Dispute Prevention and Resolution 46).

Aside from available ADR machineries, the Namibian Labour Act, 2007 and the LRA of South Africa established Labour Courts in both countries, as well as the Labour Appeal Court in South Africa, as avenues for formal litigation and for the development of jurisprudence in labour law (Van der Walt, Le Roux and Govindjee Labour Dispute Resolution (2005) 238). In South Africa, the Labour Court is separate from the High Court, although it has, in certain disputes, parallel jurisdiction. Dedicated judges who specialize in labour law preside over the Court. In contrast, Namibia's Labour Court is a division of the High Court and has no dedicated specialist judges. Any judge of the High Court can be appointed to preside over a labour matter while sitting as a Labour Court judge. This practice or system tends to compromise labour issues as they require specialization and arbiters vested with specialized skills to handle disputes effectively (Khabo Collective Bargaining and Labour Dispute Resolution (2008) 14).

In Namibia, the Labour Act permits appeal against arbitration awards on limited grounds, namely on any question of law, on a question of fact, or on a combination of these (s 89(1)(a)(b) of the Labour Act 11 of 2007). Appeal is permitted on the basis of article 12(1)(a) of the Namibian Constitution, which guarantees the right to a fair trial, as arbitration is considered a tribunal for the purpose of resolving labour disputes. In South Africa, the CCMA is an administrative body as defined in section 33 of that country's Constitution. However, there is no appeal against arbitration awards. Arbitration awards are subject to review only on limited to the grounds listed in section 145 of the LRA.

Clearly, there is no right of appeal against an arbitration award in the South African system, in contrast to Namibia where an aggrieved party has the choice to either appeal against or apply for review of the arbitration proceedings. Inherent delays in finalizing disputes are prevalent in both the South African and Namibian court systems, negating the ultimate objective of labour legislation, which sought to ensure that labour disputes are resolved expeditiously and in an efficient manner. These delays are caused by the lack of statutory established timelines within which labour disputes must be finalized by the Labour Court, particularly where the enforcement of the award is stayed. Therefore, it is submitted that this has an adverse effect on the beneficiaries of the award, particularly where the affected party continues to suffer the effects of unemployment.

\section{Recommendations for Implementation}

"It always seems impossible until it's done" - Nelson Mandela. 


\section{Experiences that can be learnt from South Africa with a view to strengthening and improving the Namibian country's labour-dispute resolution system}

In the interest of resolving labour disputes efficiently and effectively, the article recommends an adjustment to the process of arbitration in Namibia, specifically through unambiguously defined parameters as to what constitutes fair and quick determination of disputes. The current 30-day period applicable in the conciliation process and provided for in the rules of the Labour Commissioner should include arbitration proceedings. A timebound system that does not take effect only at the conclusion of the arbitration, but that operates from the effective time of referral of the dispute is required. Arbitration should not be allowed to lengthen disputes unnecessarily; its ultimate purpose of achieving quicker, fairer and equitable results must be ensured.

The Labour Act, 2007 contains a number of provisions that may be fairly perceived to have been borrowed or transplanted from South African labour law, but, unlike South Africa, Namibia did not decriminalize this branch of law. The criminal provisions in the Labour Act, 2007 have proved fruitless and difficult to enforce, thus the time has come to reconsider such provisions.

There is a prevailing trend in most SADC countries; for example, Lesotho has the Directorate of Dispute Prevention and Resolution (DDPR), established under the Labour Code (Amendment) 2000, and Swaziland has the Conciliation, Mediation and Arbitration Commission (CMAC). Making the Labour Commissioner's office independent will restore users of the system's confidence in it, particularly where Government disputes are involved.

Settlement agreements resulting from conciliation meetings have no expressed force of law in Namibia, and no statutory established mechanisms exist to enforce them. South Africa has adapted its system by creating a provision in the LRA that permits any party to the settlement agreement to apply to the CCMA to have the agreement converted to an arbitration award. Given the widespread non-compliance with settlement agreements in Namibia, social partners and policy-makers are called upon to consider an amendment to this effect. It is proposed that a provision similar to section $142 \mathrm{~A}$ of the LRA be included in the Labour Act. This will allow conciliation agreements to be enforced in the same manner as ordinary awards in terms of section 90 of the Labour Act, 2007. Moreover, conciliation settlements may be reinforced by the Labour Court in terms of section 117(1)(f) of the Labour Act, 2007.

Given the current delays in making awards enforceable, an amendment to section 87 of the Labour Act is recommended. The Labour Act currently provides for the parties or the Labour Commissioner to file the award with the court, thereby making it enforceable. In South Africa, the Director of the CCMA has statutory powers to certify the award, making it immediately final and binding and enforceable as if it were an order of court. The same approach can be adopted in Namibia to reduce the backlog experienced at 
the Labour Court and to do away with the current unclear procedure of filing arbitration awards for the purpose of enforcement.

\section{Conclusion}

This note presented ADR as a method of conflict resolution that differs from the traditional methods of adjudication and litigation. ADR institutions have been created to facilitate this, specifically the Labour Commissioner in Namibia and the CCMA in South Africa. The Labour Act, 2007 and the LRA have been enacted as legal frameworks through which labour disputes can be resolved. This includes the use of conciliation, with only a few disputes going to arbitration or, as a last resort, to the Labour Court. These institutions have been mandated to promote and implement effective strategies for dispute prevention and resolution. However, the note submits that both the Labour Commissioner and CCMA seem to be failing to realise these objectives successfully. The basis for this view is the number of cases that appear before the Labour Courts for final adjudication.

Ideally, ADR should have moved disputes away from the court-based system, which was used in the past as a battleground where labour wars were fought. However, the authors contend that ADR is not as effective as has been envisaged; disputes are not dealt with in an expeditious way nor in a friendly environment, and ADR systems consequently occasionally fail to deliver the expected quick results. These problems have created perceptions that the courts are the only avenue available to finalize labour disputes.

Disputes should be resolved as quickly and informally as possible, with little or no procedural technicalities, and without allowing them to drag on indefinitely, offering immediate solutions instead. This is far from the reality of the situation. In contrast, although the Labour Act, 2007 and the South African LRA have brought statutory dispute resolution within the reach of the ordinary worker, these Acts may have compounded the problems relating to dispute resolution in the respective countries.

Clearly, from the aforesaid, it is evident that labour-dispute resolution system in Namibia is not strictly time-bound and therefore not responsive to business and trade unions' (employees') needs and expectations. The involvement of legal practitioners at the conciliation level makes the system expensive, complicated and therefore ineffective. The outcomes often are neither quick nor fair or equitable. As a result, there has merely been a change in emphasis, from the former judicial system or cumbersome process of conciliation boards to the new ADR system. The system has shown to have failed to resolve labour disputes in the most effective manner without having to resort to the Labour Court.

Felix Musukubili

Director for Labour Services in the Ministry of Labour and Social Wefare in Namibia

Adriaan van der Walt Nelson Mandela Metropolitan University, Port Elizabeth 